\title{
Untouched Antarctica: mapping a finite and diminishing environmental resource
}

\author{
KEVIN A. HUGHES ${ }^{\mathbf{1}}$, PETER FRETWELL $^{\mathbf{1}}$, JOANNA RAE $^{\mathbf{1}}, \mathrm{KEITH}^{\text {HOLMES }}{ }^{\mathbf{2}}$ and ANDREW FLEMING ${ }^{\mathbf{1}}$ \\ ${ }^{I}$ British Antarctic Survey, NERC, High Cross, Madingley Road, Cambridge CB3 OET, UK \\ ${ }^{2} 3$ Capel Close, Oxford OX2 7LA, UK \\ kehu@bas.ac.uk
}

\begin{abstract}
Globally, areas categorically known to be free of human visitation are rare, but still exist in Antarctica. Such areas may be among the most pristine locations remaining on Earth and, therefore, be valuable as baselines for future comparisons with localities impacted by human activities, and as sites preserved for scientific research using increasingly sophisticated future technologies. Nevertheless, unvisited areas are becoming increasingly rare as the human footprint expands in Antarctica. Therefore, an understanding of historical and contemporary levels of visitation at locations across Antarctica is essential to a) estimate likely cumulative environmental impact, b) identify regions that may have been impacted by non-native species introductions, and c) inform the future designation of protected areas under the Antarctic Treaty System. Currently, records of Antarctic tourist visits exist, but little detailed information is readily available on the spatial and temporal distribution of national governmental programme activities in Antarctica. Here we describe methods to fulfil this need. Using information within field reports and archive and science databases pertaining to the activities of the United Kingdom as an illustration, we describe the history and trends in its operational footprint in the Antarctic Peninsula since c. 1944. Based on this illustration, we suggest that these methodologies could be applied productively more generally.
\end{abstract}

Received 10 January 2011, accepted 4 April 2011, first published online 25 May 2011

Key words: cumulative environmental impact, footprint, inviolate, national Antarctic programme, pristine, protected areas

\section{Introduction}

Human colonization and exploration of the Earth's continents is almost complete. Dispersal of modern human populations from Africa to the other continents began c. 65000 years ago, but mankind only reached Antarctica within the last 200 years (Mellars 2006, Headland 2009). Today few areas of the Earth's continents remain unvisited and therefore free from direct human impacts. Rarer still are areas that are known categorically to be unvisited, yet these locations will become increasingly valuable for science in the near and more distant future (Njastad 1998). Such areas may be represented in Antarctica in higher numbers and at greater spatial scales compared to other continents due to the relatively late arrival of humans and continuing low numbers of people present on the continent.

Human activities undertaken in Antarctica during the 'Heroic Age' of exploration during the late 19th-early 20th century were at a low level and largely limited to the areas around coastal expedition huts and the routes of a small number of well known inland traverses (Blanchette et al. 2004, Headland 2009). A major upsurge in the intensity of human contact with Antarctica was initiated during the International Geophysical Year of 1957/58, which has been maintained and expanded subsequently. During the past c. 65 years, the scale of human activity has increased substantially. In that time, 28 National Governmental Antarctic Programmes (NAPs) have located research stations and other infrastructure throughout the continent, although predominantly on ice-free coastal areas to facilitate easy access by ship. To date, over 120 year-round research stations have been constructed within the Antarctic Treaty area as a whole (south of latitude $60^{\circ} \mathrm{S}$ ) and 49 within the Antarctic Peninsula region. Around 75 year-round stations are currently occupied, with up to $c$. 4000 personnel during the summer, reducing to around 1000 personnel in winter (Headland 2009, COMNAP 2010). More stations are planned or under construction. From these logistic hubs, substantial science and survey work has been performed at sites dispersed throughout Antarctica. Personnel and equipment are inputted by aircraft, ship or via overland journeys involving vehicles such as tractor trains or skidoos or, in the past, by man-hauling and dog-sledge.

The tourism industry has developed largely since the 1980s and, in terms of simple numbers, brings more people to Antarctica than the NAPs; current tourist numbers are around 30000 per year supported by a further $\sim 15000$ staff and ships' crews. The majority of tourists visit Antarctic on cruise ships, with tourist landings focussed at a few ice-free locations on the northern Antarctic Peninsula (e.g. $55 \%$ of tourist landings occur at just eight sites) (Lynch et al. 2010). Compared with the NAPs, tourists 
spend 20 times less time on the continent overall, and have little permanent land-based infrastructure (Jabour 2009, IAATO 2010).

Why do we need to know where we have been?

A clear understanding of the distribution of past groundbased field activities has clear benefits for environmental management by:

a) identifying areas at potential risk of cumulative environmental impact both around and away from research stations and visitor sites (Kennicutt et al. 2010),

b) identifying regions that may already have been impacted by non-native species introductions, thereby allowing policy makers and operators to implement appropriate biosecurity measures (Hughes \& Convey 2010),

c) revealing impact-free areas that may be preserved for future science or wilderness values (Njastad 1998),

d) informing the future designation of protected areas so they can be managed systematically under the Antarctic Treaty protected area system (see: http:// www.ats.aq/e/ep_protected.htm).

Recognition of the need for areas protected as pristine and largely unvisited sites is not new. Forty years ago, Cameron suggested that a 'conservative attitude towards preservation and pollution of the Antarctic also may be in order at this time so as to maintain some of its pristinity for future generations' (Cameron 1972). At a joint Scientific Committee for Antarctic Research (SCAR)/International Union for Conservation of Nature (IUCN) workshop on Antarctic protected areas in 1992, it was suggested that extensive areas 'could serve as valuable biologically and chemically uncontaminated sites, never visited by people or overflown by low-flying aircraft' (Lewis Smith 1994; Appendix 1). Six years later, the report of the ATCM Antarctic Protected Areas workshop (23 May 1998, Tromso, Norway) suggested that large areas of pristine or near pristine nature should be set aside for a long time (Njastad 1998). In terms of priority for protection, areas kept inviolate from human interference were allocated the highest level of priority as 'if we wait too long, hardly any sites will be left where impact has not already occurred, due to the increasing pressures of visits to previously unvisited sites'. Little progress has been made towards this goal in the intervening 13 years.

\section{Human impacts}

Given Antarctica's vast size $\left(14000000 \mathrm{~km}^{2}\right)$, lack of indigenous population and relatively few visitors to the region, it could be assumed that environmental impact was negligible (COMNAP 2010, IAATO 2010). However, this is not the case due to the heterogeneous spatial distribution of human activities throughout the continent that has put the terrestrial environment under increasing pressure in some areas. Over a number of years, visited and inhabited sites can experience a range of impacts including chemical pollution (Wilkness 1990, Sheppard et al. 2000, Bargagli 2005, Santos et al. 2005, Tin et al. 2009, Kennicutt et al. 2010), sewage release (Hughes 2003, 2004, Hughes \& Blenkharn 2003, Conlan et al. 2004, Smith \& Riddle 2009) and disturbance of local plant, bird and marine mammal populations (ASOC 2004, Braun et al. in press), while the introduction of non-native species on ships, aircraft, cargo, food and visitors' clothing may threaten vulnerable Antarctic ecosystems (Frenot et al. 2005, Whinam et al. 2005, Lee \& Chown 2009a, 2009b, Hughes \& Convey 2010, Hughes \& Worland 2010, Hughes et al. 2010). Furthermore, poor environmental practice, generally pre-dating the implementation of the Protocol on Environmental Protection to the Antarctic Treaty (also known as the Madrid or Environmental Protocol; signed in 1991, entered into force 1998; ATCP 1991) has left a legacy of abandoned waste dumps and contaminated ground in the marine and terrestrial environments around some research stations (Tin et al. 2009). Tourist impacts may also be magnified by concentration at a few highly-visited locations, although site-specific guidelines have been produced to keep environmental impact to a minimum (Lee \& Hughes 2010) (see the Antarctic Treaty's site guidelines for visitors at http://www.ats.aq/e/ats_other_ siteguidelines.htm, and International Association of Antarctica Tour Operator (IAATO) guidelines at http://www.iaato.org/ guidelines.html).

At more remote locations, even short duration visits by small numbers of people can cause negative environmental impacts. Multiple field activities at a remote location, individually assessed to have a 'less than minor or transitory' impact, may together amount to a substantially greater degree of impact (France 2008). Examples may include:

a) the homogenization (genetic dilution) of Antarctica's biota through human-mediated transfer of native Antarctic species (Frenot et al. 2005, Chown \& Convey 2007, Hughes \& Convey 2010),

b) introduction of non-native species including the long-term contamination of pristine sites by humanassociated microbiota (Meyer et al. 1963, Cameron 1972, Broady \& Smith 1994, Nedwell et al. 1994, Sjoling \& Cowan 2000, Baker et al. 2003),

c) engine emissions and chemical pollution (Bargagli 2005, Tin et al. 2009),

d) direct physical impacts at sites of concentrated activity (Chen \& Blume 1997, Campbell et al. 1998, Tejedo et al. 2009, Braun et al. in press).

Before the implementation of the Environmental Protocol, waste was often discarded in the field. Dog sledge travel resulted in the widespread deposition of dog faecal waste in limited areas such as the Peninsula (Walton \& Atkinson 1996). 
Table I. UK research stations, refuges ${ }^{1}$ and major depots (1944-2010).

\begin{tabular}{|c|c|c|c|c|c|c|c|c|c|c|c|c|c|c|}
\hline Abbr. & Station name & Lat & Long & $\begin{array}{l}\text { No. years } \\
\text { occupied }\end{array}$ & 40 & 50 & 60 & 70 & 80 & 90 & 00 & $\begin{array}{l}\operatorname{Size}^{2} \\
(1-5)\end{array}$ & $\begin{array}{l}\text { Occupancy } \\
*\end{array}$ & Current status \\
\hline A & Port Lockroy & $64^{\circ} 49^{\prime} \mathrm{S}$ & $63^{\circ} 30^{\prime} \mathrm{W}$ & 15 & $\mathbf{\square}$ & 口 & $\mathbf{\square}$ & & & $\mathbf{\square}$ & 口 & 2 & 75 & Historic Site No. 61. \\
\hline B & Deception Island Station & $62^{\circ} 59^{\prime} \mathrm{S}$ & $60^{\circ} 34^{\prime} \mathrm{W}$ & 24 & $\mathbf{\square}$ & $\mathbf{\square}$ & $\mathbf{\square}$ & & & & & 4 & 161 & $\begin{array}{l}\text { Partially collapsed. Partially cleaned up 1990-92. } \\
\text { Aircraft operations hub. }\end{array}$ \\
\hline BL & Blaiklock Island & $67^{\circ} 32^{\prime} \mathrm{S}$ & $67^{\circ} 12^{\prime} \mathrm{W}$ & 1 & & $\mathbf{\square}$ & & & & & & 1 & 0 & Closed. Part of Historic Site No. 63 \\
\hline$C(1)$ & Sandefjord Bay & $60^{\circ} 37 ' \mathrm{~S}$ & $46^{\circ} 02^{\prime} \mathrm{W}$ & - & 口 & & & & & & & 2 & 0 & Never occupied. Collapsed 1950s \\
\hline $\mathrm{C}(2)$ & Cape Geddes & $60^{\circ} 41^{\prime} \mathrm{S}$ & $44^{\circ} 34^{\prime} \mathrm{W}$ & 1 & 口 & & & & & & & 2 & 4 & Closed. \\
\hline $\mathrm{CR}$ & Cape Reclus & $64^{\circ} 30^{\prime} \mathrm{S}$ & $61^{\circ} 46^{\prime} \mathrm{W}$ & 2 & & $\mathbf{\square}$ & & & & & & 1 & 0 & Dismantled and removed 1996 \\
\hline $\mathrm{D}$ & Hope Bay & $63^{\circ} 24^{\prime} \mathrm{S}$ & $57^{\circ} 00^{\prime} \mathrm{W}$ & 16 & 口 & [ & $\mathbf{\square}$ & & & & & 4 & 186 & Transferred to Uruguay 1997 \\
\hline DP & Damoy Point & $64^{\circ} 48^{\prime} \mathrm{S}$ & $63^{\circ} 30^{\prime} \mathrm{W}$ & 11 & & & & $\mathbf{\square}$ & 口 & $\mathbf{\square}$ & & 2 & 0 & Closed. Cleaned-up 2007. Skiway. Historic Site No. 84 \\
\hline E & Stonington Island & $68^{\circ} 11^{\prime} \mathrm{S}$ & $67^{\circ} 00^{\prime} \mathrm{W}$ & 20 & 口 & [ & $\mathbf{\square}$ & $\mathbf{\square}$ & & & & 4 & 233 & Closed. Historic Site No. 64. \\
\hline $\mathrm{F}$ & Faraday & $65^{\circ} 15^{\prime} \mathrm{S}$ & $64^{\circ} 16^{\prime} \mathrm{W}$ & 49 & [ & [ & $\mathbf{\square}$ & $\mathbf{\square}$ & 口 & $\mathbf{\square}$ & & 4 & 521 & Transferred to Ukraine in 1996 \\
\hline G & Admiralty Bay & $62^{\circ} 05^{\prime} \mathrm{S}$ & $58^{\circ} 22^{\prime} \mathrm{W}$ & 14 & [ & [ & $\mathbf{\square}$ & & & & & 3 & 79 & Demolished and removed 1996 \\
\hline $\mathrm{H}$ & Signy Research Station & $60^{\circ} 43^{\prime} \mathrm{S}$ & $45^{\circ} 36^{\prime} \mathrm{W}$ & 62 & 口 & [ & $\mathbf{\square}$ & $\mathbf{\square}$ & 口 & $\mathbf{\square}$ & 口 & 4 & 524 & Summer-only station since 1996 \\
\hline $\mathrm{J}$ & Prospect Point & $66^{\circ} 00^{\prime} \mathrm{S}$ & $65^{\circ} 21^{\prime} \mathrm{W}$ & 2 & & [ & & & & & & 2 & 11 & Demolished and removed 2004 \\
\hline KG & Fossil Bluff & $71^{\circ} 20^{\prime} \mathrm{S}$ & $68^{\circ} 17^{\prime} \mathrm{W}$ & 48 & & & $\mathbf{\square}$ & $\mathbf{\square}$ & $\mathbf{\square}$ & $\mathbf{\square}$ & 口 & 2 & 40 & Fuel depot and airstrip. Currently open summer-only \\
\hline $\mathrm{N}$ & Anvers Island & $64^{\circ} 46^{\prime} \mathrm{S}$ & $64^{\circ} 05^{\prime} \mathrm{W}$ & 7 & & $\mathbf{\square}$ & & $\mathbf{\square}$ & & & & 2 & 17 & Destroyed. Cleaned up 1990/91. Ski-way. \\
\hline $\mathrm{O}$ & Danco Island & $64^{\circ} 44^{\prime} \mathrm{S}$ & $62^{\circ} 36^{\prime} \mathrm{W}$ & 3 & & $\mathbf{\square}$ & & & & & & 2 & 17 & Demolished and removed 2004 \\
\hline $\mathrm{OC}$ & Orford Cliff & $66^{\circ} 55^{\prime} \mathrm{S}$ & $66^{\circ} 29^{\prime} \mathrm{W}$ & 2 & & $\mathbf{\square}$ & & & & & & 1 & 0 & Demolished and removed 1997 \\
\hline $\mathrm{P}$ & Livingston Island & $62^{\circ} 40^{\prime} \mathrm{S}$ & $61^{\circ} 00^{\prime} \mathrm{W}$ & 1 & & $\mathbf{\square}$ & & & & & & 1 & 0 & Dismantled 1950s \\
\hline $\mathrm{R}$ & Rothera & $67^{\circ} 34^{\prime} \mathrm{S}$ & $68^{\circ} 08^{\prime} \mathrm{W}$ & 35 & & & & $\mathbf{\square}$ & 口 & $\mathbf{\square}$ & 口 & 5 & 595 & Operation year-round. Rock airstrip \\
\hline $\mathrm{RS}$ & Rasmussen Hut & $65^{\circ} 15^{\prime} \mathrm{S}$ & $64^{\circ} 06^{\prime} \mathrm{W}$ & 12 & & & & & $\mathbf{\square}$ & $\mathbf{\square}$ & & 1 & 0 & Transferred to Ukraine in 1996 \\
\hline SB & Sky Blu & $74^{\circ} 51^{\prime} \mathrm{S}$ & $71^{\circ} 34^{\prime} \mathrm{W}$ & 14 & & & & & & $\mathbf{\square}$ & 口 & 2 & 0 & Blue ice airstrip. Open summer-only \\
\hline $\mathrm{T}$ & Adelaide & $67^{\circ} 46^{\prime} \mathrm{S}$ & $68^{\circ} 55^{\prime} \mathrm{W}$ & 16 & & & $\mathbf{\square}$ & $\mathbf{\square}$ & & & & 4 & 166 & Transferred to Chile 1984 \\
\hline $\mathrm{V}$ & View Point & $63^{\circ} 33^{\prime} \mathrm{S}$ & $57^{\circ} 21^{\prime} \mathrm{W}$ & 11 & & $\mathbf{\square}$ & $\mathbf{\square}$ & & & & & 2 & 0 & Transferred to Chile 1996 \\
\hline $\mathrm{W}$ & Detaille Island & $66^{\circ} 52^{\prime} \mathrm{S}$ & $66^{\circ} 48^{\prime} \mathrm{W}$ & 3 & & $\mathbf{\square}$ & & & & & & & 27 & Closed. Cleaned up 2003/04. Historic Site No. 83 . \\
\hline $\mathrm{Y}$ & Horseshoe Island & $67^{\circ} 48^{\prime} \mathrm{S}$ & $67^{\circ} 17^{\prime} \mathrm{W}$ & 6 & & [ & $\mathbf{\square}$ & & & & & 4 & 44 & Closed. Historic Site No. 63 \\
\hline Z & Halley Bay & $75^{\circ} 35^{\prime} \mathrm{S}$ & $26^{\circ} 34^{\prime} \mathrm{W}$ & 53 & & $\mathbf{\square}$ & $\mathbf{\square}$ & $\mathbf{\square}$ & 口 & $\mathbf{\square}$ & $\mathbf{\square}$ & 5 & 1029 & $\begin{array}{l}\text { Series of } 6 \text { year-round stations on Brunt Ice Shelf } \\
\text { since 1956. Skiway. }\end{array}$ \\
\hline \multicolumn{15}{|l|}{ Total } \\
\hline \multicolumn{2}{|c|}{26 stations \& refuges and depots } & $60-75^{\circ} \mathrm{S}$ & $26-68^{\circ} \mathrm{W}$ & 439 & 8 & 18 & 12 & 9 & 8 & 10 & 6 & & 3789 & $\begin{array}{l}\text { Occupied stations: } 2 \text { year-round, } 1 \text { summer-only, } \\
1 \text { Historic Site, } 2 \text { summer-only air-strips }\end{array}$ \\
\hline
\end{tabular}

* Total wintering population only

${ }^{1}$ Other huts around Signy Island, South Orkney Islands and Argentine Islands. Stations on South Georgia are not included in the table.

2 Estimate of station size at its largest. 


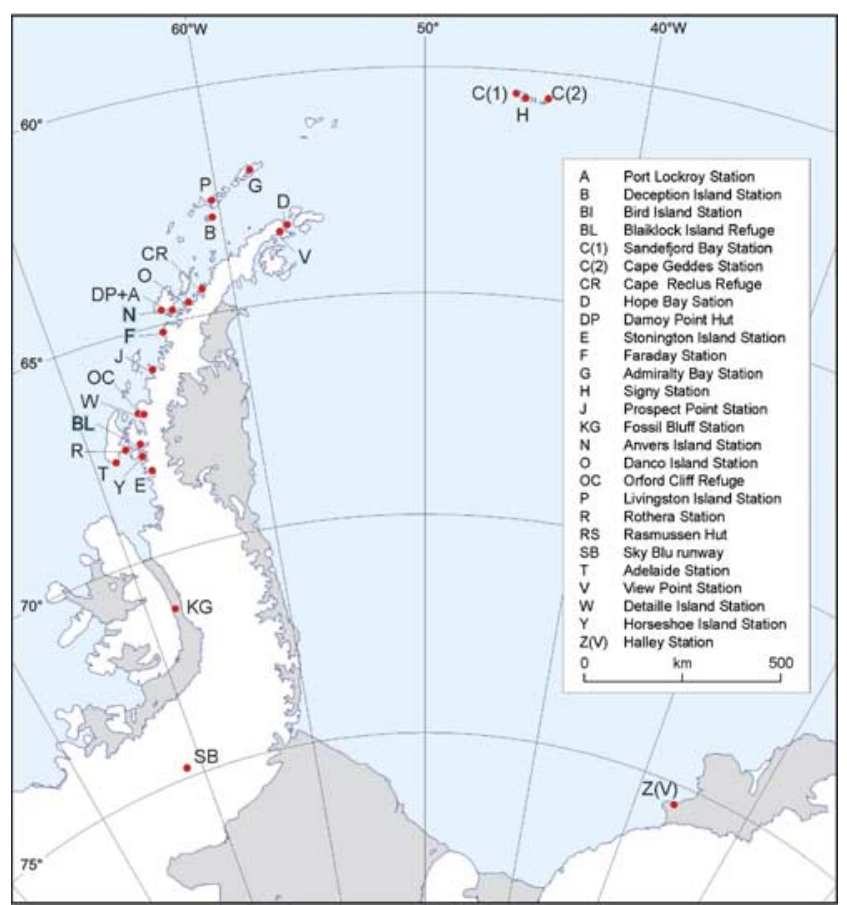

Fig. 1. Present and past UK research stations on the Antarctic Peninsula.

In recent years, regional warming in the Antarctic Peninsula has caused a decrease in permanent snow cover and previously buried toilet pits, depots and food dumps have melted out (Fox \& Cooper 1998, Hughes \& Nobbs 2004). In other areas, fuel and food depots have been lost due to snow accumulation.

For a given location, quantifying the impact of an individual activity has limited practical use, unless it can be placed in the context of the total impacts at that site over time, i.e. cumulative environmental impact. Generally, the assessment of the cumulative environmental impact of man's activities is rarely undertaken at major centres of activity in Antarctica, and has received little attention at more dispersed locations away from the hubs of human activity (Hughes 2010, Kennicutt et al. 2010).

\section{Availability of existing information}

Much of the activity of the tourism industry over the past 20 years is freely available as location-specific data (see IAATO 2010). In that time over 2000000 person landings have been made at around 337 coastal Peninsula locations. In contrast, information detailing the exact locations of NAP past activities is not readily available, although some general information is made available through the Council of Managers of National Antarctic Programs (COMNAP; www.comnap.aq). The Environmental Protocol states that each Treaty Party 'shall, as far as is practicable, also prepare an inventory of locations of past activities (such as traverses, field depots, field bases, crashed aircraft) before the information is lost,
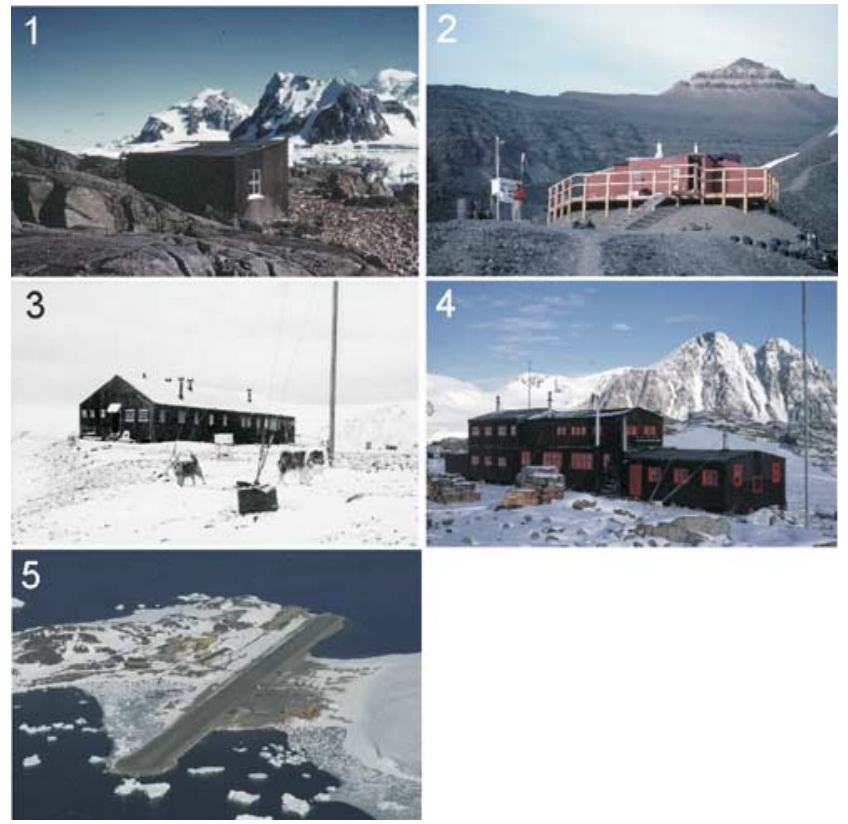

Fig. 2. Examples of Antarctic research stations to illustrate relative size: (1) Blaiklock Island refuge, 1957, by George M. Larmour, BAS Archives Ref. AD6/19/3/C/Y11, (2) Station KG, Fossil Bluff, 1994/95, by Peter Bucktrout, BAS Image Collection Ref. 10004058, (3) Station G, Admiralty Bay, 1958/59, by Denis R. Bell, BAS Archives Ref. AD6/19/X/20/1, (4) Station E, Stonington Island, 1973/74, photographer unknown, BAS Archives Ref. AD6/19/3/C/E29, and (5) Rothera Research Station, 2009/10, by Peter Bucktrout, BAS Image Collection Ref. 10010169.

so that such locations can be taken into account in planning future scientific programs (such as snow chemistry, pollutants in lichens or ice core drilling)' [Article 8(3)]. To some degree this obligation is fulfilled by the Antarctic Treaty's Information Exchange and the Electronic Information Exchange System (EIES; http://www.ats.aq/e/ie.htm) which provide an overview of NAP activities. However, the system is limited in its usefulness for estimating the extent and intensity of human activities as:

a) only around $60 \%$ of Antarctic Treaty Parties submit information on their activities to the Information Exchange database, despite it being an obligation under the Antarctic Treaty (calculation based on 2008/09 data),

b) the information provided includes details of only major field activities,

c) sufficient information is not always included to enable identification of specific locations of field activities and, in particular, those of travelling field parties,

d) information outside the EIES is not readily accessible, and

e) substantial quantities of human activity pre-dated the period covered by the Information Exchange process. 


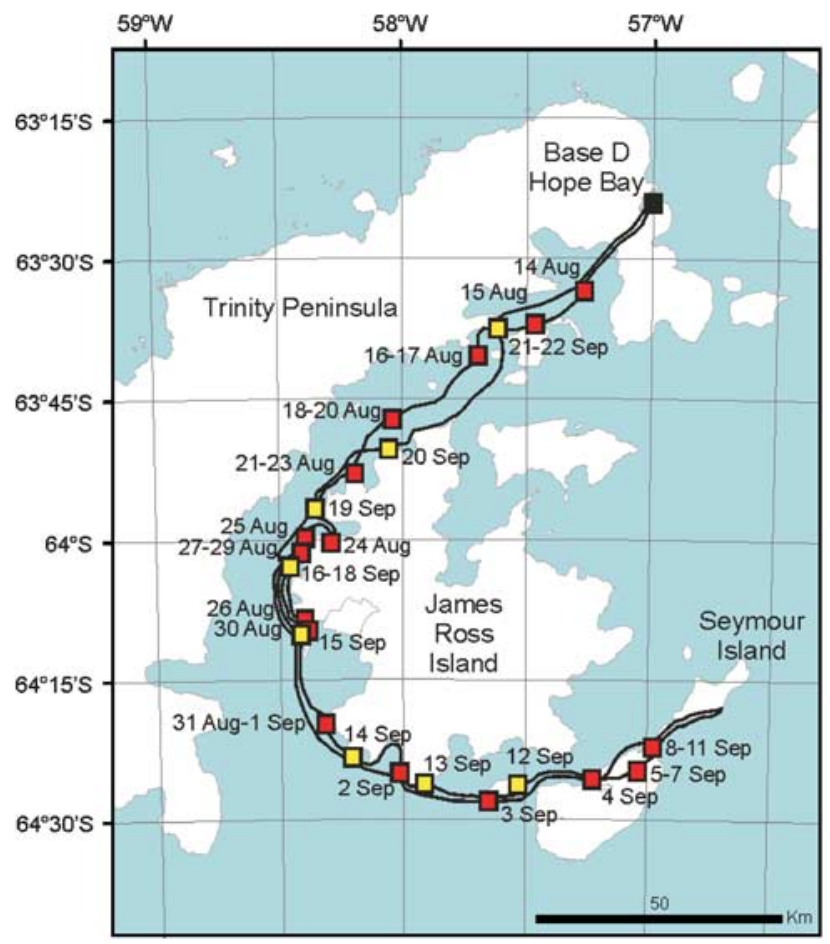

Fig. 3. Example of a 1952 dog-sledging route extracted from archived sledge party field reports (red square $=$ outward journey camp locations, yellow square $=$ return journey camp locations). Much of the journey was undertaken on winter sea ice.

In recent years the Antarctic Treaty Consultative Meeting (ATCM) through its Committee for Environmental Protection (CEP) has paid attention to the topic of cumulative environmental impact by the tourism industry and governmental operators. The CEP reported a need to determine the footprint of human impact for multiple activities and operators at the local, regional and continentwide scale (United States 2003). A priority for future work was the 'establishment of databases (spreadsheets, GIS) capturing field and station activities through time', but a recommendation to develop a readily accessible database detailing NAP site visitation has yet to be implemented.

In this paper, as an illustration of potential approaches to advance knowledge in this field, we apply methods that attempt to determine the footprint of the United Kingdom's NAP, focussing primarily on the Antarctic Peninsula region. This provides an example of a NAP where formal locationspecific records of activities are not readily available.

\section{Methods}

The British Antarctic Survey (BAS) is the United Kingdom's national operator within Antarctica. BAS is one of 17 NAPs with research stations and/or significant scientific activities in the Antarctic Peninsula. It has an active scientific programme, good transportation infrastructure and a long historical

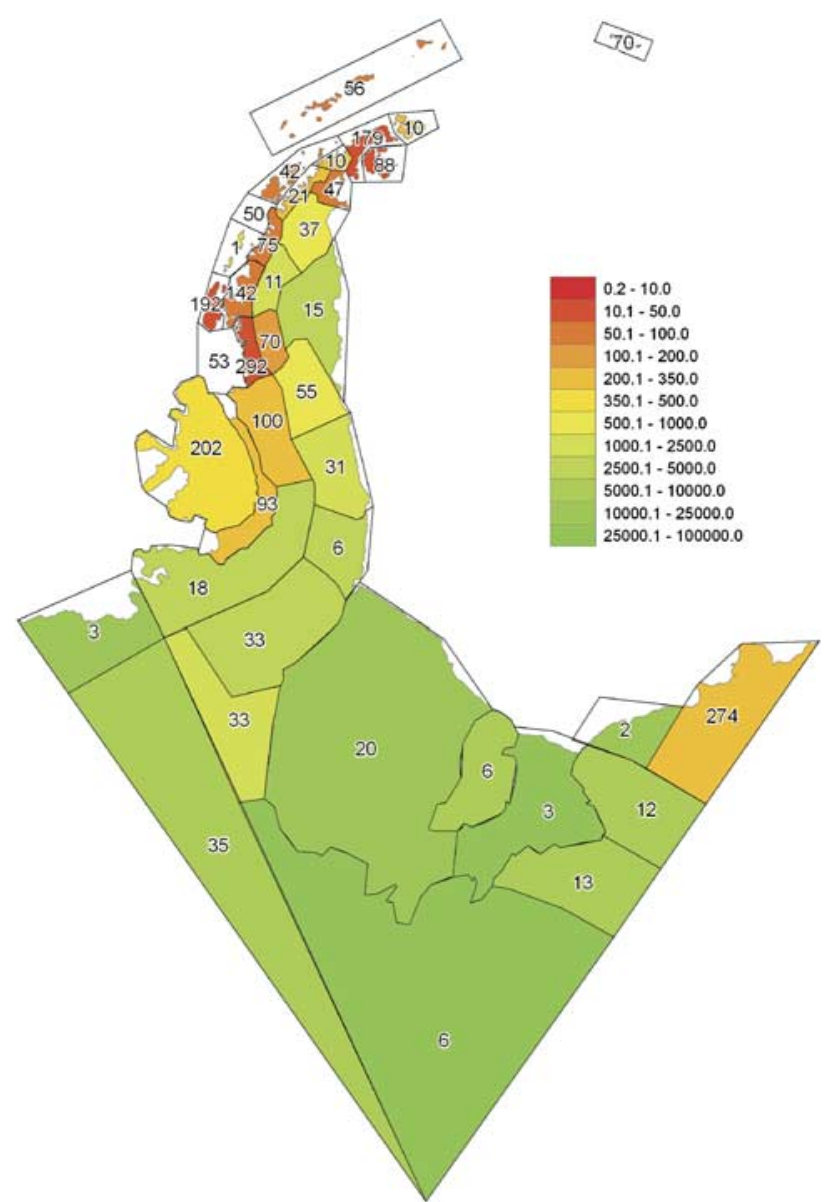

Fig. 4. Location of activities based upon BAS Archives database sub-regions. The number of field reports from each region is indicated on the map. The scale units are the number of $\mathrm{km}^{2}$ per record.

presence in the region. The UK has maintained permanently staffed research stations on the Antarctic Peninsula since 1944, when a British Government military expedition, Operation Tabarin, opened two stations. The operation was established on a permanent basis as the Falkland Island Dependencies Survey (FIDS) in 1945, and a further 19 stations were opened before 1962, when FIDS was renamed BAS.

\section{Research station infrastructure}

For each UK research station, information on location, period occupied and total number of wintering personnel was extracted from documents held in the BAS Archive and the BAS Club Database of Wintering Staff (http:// www.antarctica.ac.uk/basclub/news/winterers.php).

\section{Field activities: archived field reports}

Since 1944 British field parties operating under BAS or its predecessors have produced unpublished/internal reports describing their journeys and scientific/survey findings. 


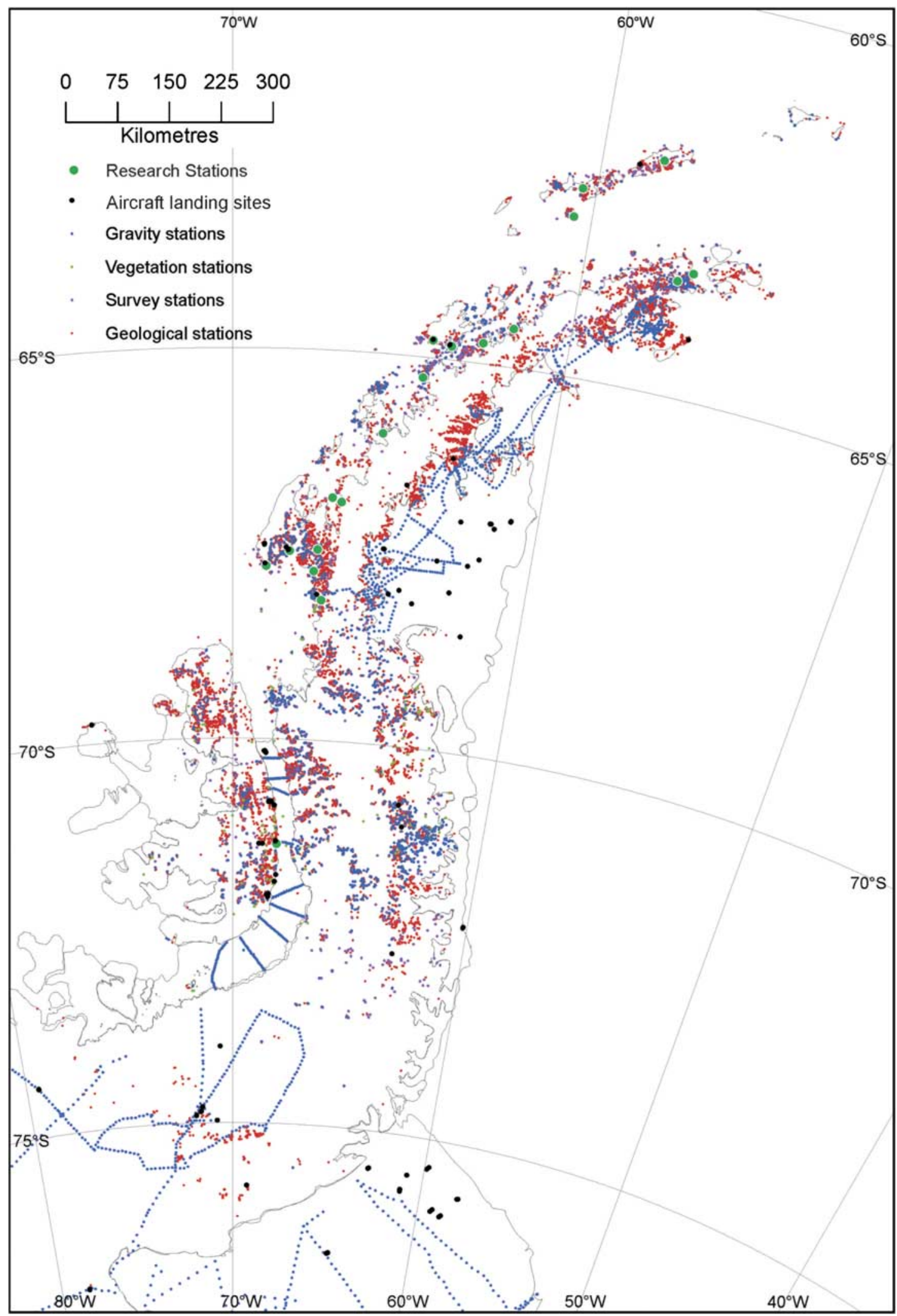

Fig. 5. Location of BAS logistic infrastructure (depot sites, past and present research stations) and field activities on ice-free locations and ice sheets and ice shelves (geophysical traverse lines, and ice-core drill sites) derived from readily accessible databases. 
The BAS Archives holds over 9500 such reports. Of these 2020 are travel reports, including 722 with maps plotting travel routes and campsites. The travel reports are often the first, and sometimes only, record of visits to remote localities. Separate scientific field reports covering the same journey can be used to supplement the information in the travel reports, although their focus is on the scientific work sites rather than the routes. The BAS Archives hold just under 500 geology and geophysics field reports, about 200 glaciology reports, 240 topographic survey reports and 700 terrestrial biology reports. Together these provide a valuable source of detailed information about the localities visited. Nevertheless, their usefulness is dependent on the accuracy of the original location recordings, the ability to geo-reference the data to modern maps and the availability of sufficient time and manpower to extract and analyse the data. As an example, the route and field camps of a geological field party detailed in BAS Archive report numbers AD6/2D/1952/K5 (travel) and AD6/2D/1952/G (geology) were plotted.

\section{Field activities: archive field report databases}

Owing to the resource requirements of extracting data from the field reports themselves, alternative ways of viewing these data were examined. All the field reports held in the BAS Archives have been catalogued and indexed by geographical place. Focussing on the Antarctic Peninsula area, the number of field reports indexed to each of 38 geographical sub-regions (coasts and island groups) between approximately $90^{\circ} \mathrm{W}$ and $20^{\circ} \mathrm{E}$ was used as a proxy for estimating spatial distribution of British field activities over the past 65 years. The sub-regions were designated arbitrarily to give pragmatic coverage of the region when the current archive system was developed in 1986. To allow for differences in the area of the subregions, the number of field reports was plotted relative to the sub-region area and expressed as $\mathrm{km}^{2}$ per record. For example, the Adelaide Island sub-region $\left(4663 \mathrm{~km}^{2}\right)$ on the western Antarctic Peninsula, had 192 reports resulting in $4663 / 192=24.3 \mathrm{~km}^{2}$ per record (i.e. within the scale range $10.1-50.0 \mathrm{~km}^{2}$ per record).

\section{Field activities: science and mapping databases}

An estimate or proxy for the spatial extent, concentration and chronology of UK national operator activities in Antarctica was generated using location data held in science and mapping databases. The UK Antarctic Plant Database (see http://apex.nerc-bas.ac.uk/f?p=252:1), Mapping and Survey databases and Geological Database contain records of locations visited throughout the Antarctic Peninsula area with the majority dating from after the 1940s. These database records therefore provide information on the positions and dates of ground-based field activities. Over 58000 records with associated locations are held in the

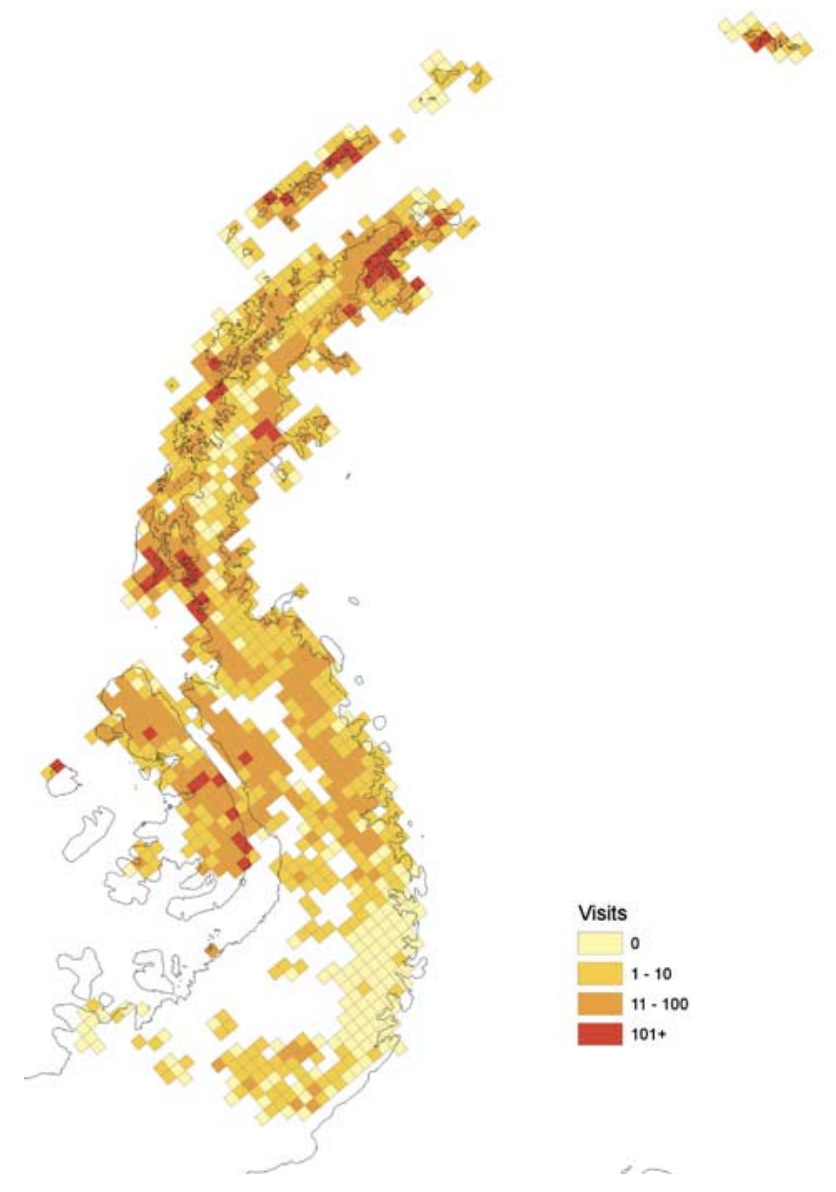

Fig. 6. Number of recorded field activities within $20 \times 20 \mathrm{~km}$ squares that contain ice-free locations in the Peninsula region. Areas containing no ice-free ground are shown in white.

databases. Firstly, all the positional data were plotted to show the extent of UK activities, including fieldwork locations, past and present research stations, aircraft landing and depot sites and field activities on ice-free locations and ice sheets and ice shelves (e.g. geophysical traverse lines and ice-core drill sites). Secondly, the data were used to determine the concentration of human activity in ice-free locations on the Peninsula at a fine spatial scale using $20 \times 20 \mathrm{~km}$ grid squares (1014 squares in total) and quantifying the number of visits to each grid square. Lastly, the data was used to examine the chronological development of UK activities in the region by plotting separately the location of field activities undertaken before 1949 and during every subsequent decade up until 2009.

\section{Results}

\section{Research stations infrastructure}

Table I shows details of the 26 UK research stations and huts in Antarctica occupied since 1944, and Fig. 1 shows 

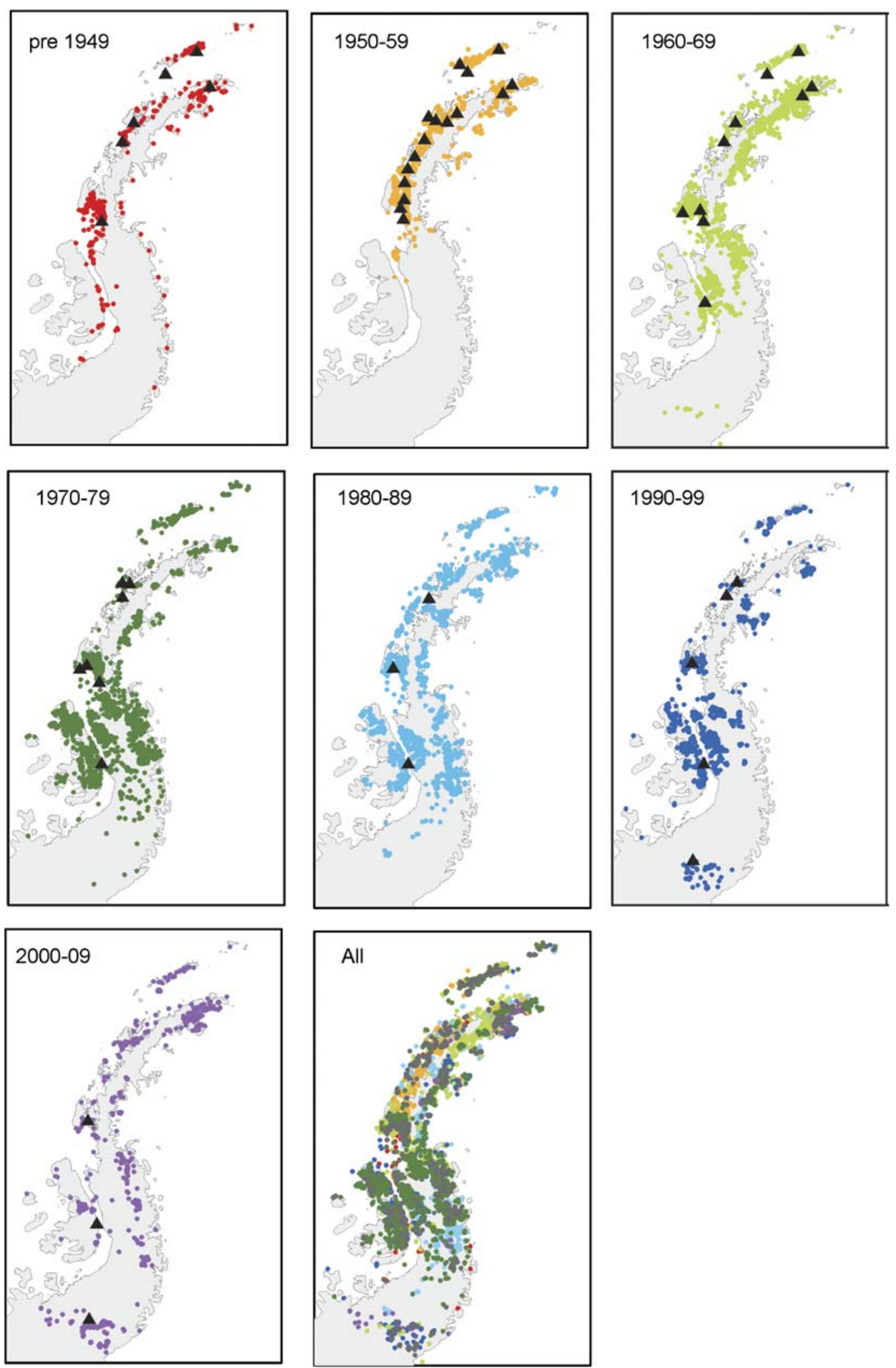

Fig. 7. Distribution of field activity locations on ice-free locations each decade up until 2009 (South Orkney Islands not shown). The location of research stations occupied during the decade are shown in each panel $(\mathbf{\Delta})$. 
their locations on the Antarctic Peninsula (only Halley Research Station lies outside the Antarctic Peninsula region). Figure 2 illustrates differences in relative size, as detailed in Table I.

Station numbers peaked in the 1950 s, coinciding with the UK's scientific efforts toward the International Geophysical Year 1957/58. After this time station numbers gradually declined and currently Rothera Research Station is the only UK station on the Antarctic Peninsula that is occupied year-round. Unused research stations were either transferred to other Antarctic Treaty nations (e.g. Faraday was transferred to the Ukraine in 1996 and renamed Vernadsky Station), demolished and removed (e.g. Station G: Admiralty Bay), or designated as a Historic Site and Monument (HSM) under the Antarctic Treaty System (e.g. Station Y: Horseshoe Island). Assessing the duration of human occupancy in Antarctica is difficult, with individuals spending between a few weeks to over 2.5 years. However, in recent years typically over 250 personnel visit BAS stations and field locations each year, with around 40 overwintering. Since the 1940s this gives the equivalent of almost 4000 Antarctic 'person winters' undertaken at UK research stations. All stations were constructed on ice-free ground with direct ship access, with the exceptions of Fossil Bluff (on rock, adjacent to George VI Ice Shelf), Sky Blu (inland, on blue ice) and Halley Research Station (coastal, on the Brunt Ice Shelf).

\section{Field activities: archived field reports, field report databases and science and mapping databases}

Figure 3 shows the route and field camps of a geological field party on a return dog sledge trip from Base D Hope Bay, Trinity Peninsula to Seymour Island via James Ross Island between 14 August and 22 September 1952, deduced from archive reports. Much travel was performed on seasonal sea ice, but also over permanently ice covered land. Figure 4 shows the levels of BAS field activities integrated within 38 sub-regions across the Antarctic Peninsula area. The highest levels of field activity were on the South Orkney Islands and northern and western Antarctic Peninsula.

Figure 5 shows the extent of UK field activities and the location of UK logistic infrastructure including aircraft landing and depot sites, past and present research stations, geophysical traverse lines and ice-core drill sites. Figure 6 shows the concentration of field activity locations up until 2009 in $20 \times 20 \mathrm{~km}$ grid squares within which are found ice-free locations in the Peninsula region. The highest concentrations of visits were found around the sites of current and past research stations. Figure 7 shows the distribution of field activity locations, held in the UK databases, before 1949 and each decade up to 2009, and illustrates how the location of scientific effort has changed over time and is linked to active research station distribution.

\section{Discussion}

Effectiveness of the methodologies: United Kingdom operational footprint as a case study

The methods described here have produced a detailed spatial and temporal representation of UK activities in the Antarctic Peninsula. Nevertheless, with these methodologies, the accuracy of any representation depends upon the quality and quantity of data in available databases. The methods do not show directly the magnitude of potential human impacts associated with each location (for instance, not differentiating between a location visited by one person for five minutes or ten people for a week, or classifying the activities carried out at a location), although some of this information may be available in the associated field reports. Neither do the techniques provide information on the levels of any impacts associated with travel between locations. Extracting information from archived field reports is a time-consuming task, but may prove useful for assessing impacts at remote/ little visited locations.

Despite these limitations, the methods reveal the considerable expansion of British operations throughout the Antarctic Peninsula region over the past seven decades. The distribution, scale and number of stations has varied considerably, largely driven in earlier years by the priority of mapping and exploring the region and, more latterly, of focussing on critical science questions facilitated by increasingly sophisticated research techniques (Fig. 6). The 1940s saw the establishment of the long-term presence of the UK in the region and was a period when much exploration by ship and dog sledge was undertaken as the geography of the Antarctic Peninsula was relatively poorly known at that time. Around 900 dogs were kept at major UK Antarctic stations between 1944 and 1994, with c. $540000 \mathrm{~km}$ travelled by dog teams over this period (Walton \& Atkinson 1996). During the 1950s more detailed survey activity focussed around the research stations on the northern and western Antarctic Peninsula (Graham Land). High numbers of sampling and survey locations recorded during 1960s, 1970s and 1980s coincide with major periods of geological survey in the region. The increased use of aircraft for field science support and the opening of station KG (Fossil Bluff, Alexander Island) in the 1960s increased science activity in the southern Peninsula (Palmer Land) and on the eastern side of the northern Peninsula. From the mid 1970s, the use of dog teams as the primary means of land transport was phased out in favour of skidoos input by aircraft, thereby greatly reducing human impact caused by traversing to scientific work sites. In the 1970 s and 1980 s, work on the northern Peninsula continued, while most of Alexander Island was surveyed along with adjacent ice-free areas on the mainland Peninsula.

By the 1990s the period of major survey effort was drawing to close and the level of work in the northern Peninsula declined. Most science in the region was 


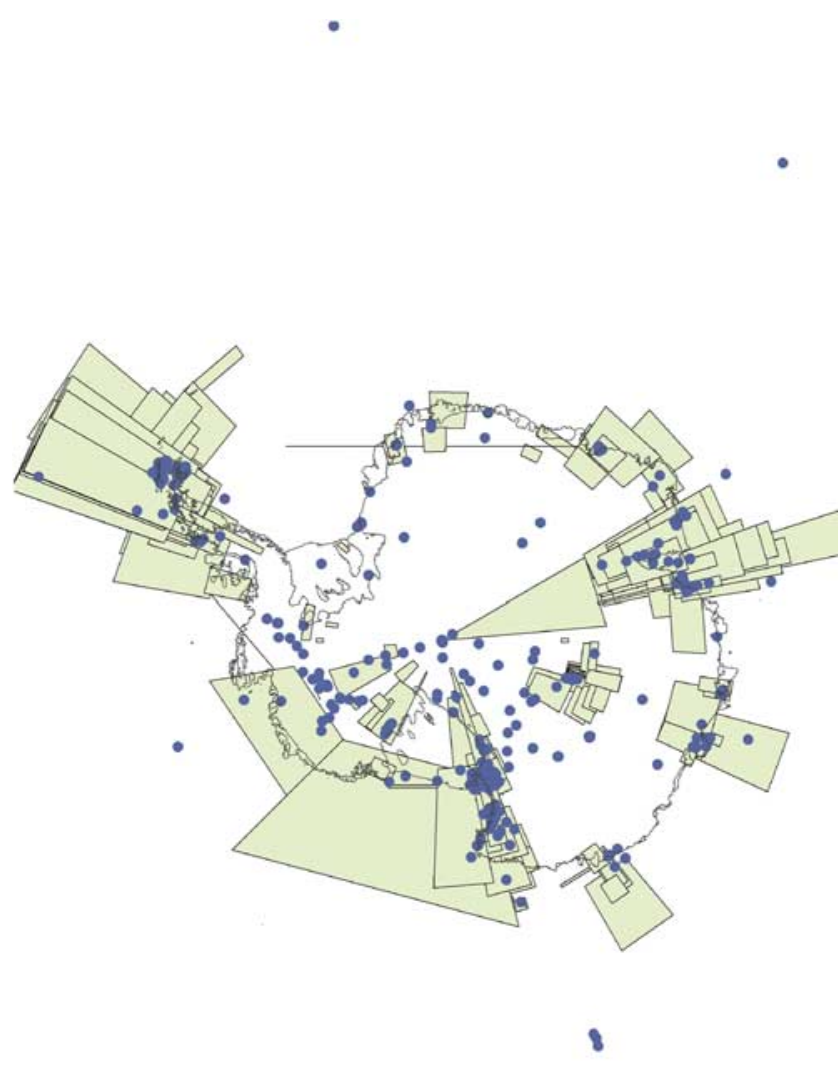

8

Fig. 8. Distribution of marine and terrestrial scientific databases within the Antarctic Treaty area described in the Antarctic Master Directory. Databases shown are those described as point locations (1367) or have area coverage less than $15 \times 15$ degrees (1444). Databases with larger area coverage are not shown (1887). Each database may contain multiple locations of individual field activities.

performed using the air corridor that connected the newly constructed runway at Rothera Research Station with Fossil Bluff and the newly opened blue ice runway at Sky Blu (Ellsworth Land). The new millennium saw increasingly strategic use of BAS logistics to answer major scientific questions, resulting in a more focussed deployment of scientists, complemented by an increased reliance on remote geophysical techniques.

In general, levels of human activity are focussed in areas in the vicinity of established research stations (see Figs 1, $6 \& 7$ ). Although the number of active stations has fallen from a peak of 18 during the 1950s to six today, in the same period the footprint of British activities has expanded across the entire Antarctic Peninsula and beyond. Likewise, the NAPs of some Antarctic Treaty nations with a shorter presence in the region, are also now expanding their infrastructure and operational footprint in Antarctica. For example, South Korea and India are soon to join the nine other Treaty Parties with more than one permanently occupied Antarctic research station, with their new stations being located a considerable distance from the existing operation. Today, BAS supports research throughout Antarctica, often as part of international collaborative projects and cooperatively using the infrastructure of other nations (e.g. the Antarctica's Gamburtsev Province Project (AGAP), located on the East Antarctic ice shelf; see http://www.antarctica.ac.uk/press/featured/AGAP/hidden_ world.php).

\section{Wider application of techniques}

The representations of human activity distributions detailed in Figs 5-7 were generated using only three datasets, all originating from within the UK. Figure 8 shows the spatial areas covered by $c .4700$ dataset descriptions held within the Antarctic Master Directory (found at: http://idn.ceos. org/portals/Home.do?Portal =amd\&MetadataType $=0$ ), which was put in place predominantly by the Standing Committee on Antarctic Data Management (SCADM) network of National Antarctic Data Centres and contains spatial information placed there by universities, commercial organizations, NGOs, science consortia and multinational organizations and government agencies based in many different nations. The combination and subsequent visualization of the locations held within all other Antarctic Treaty Parties' datasets could provide a powerful representation of the distribution of human impact for multiple activities and operators within Antarctica - a goal clearly set out at the CEP (United States 2003). The addition of information on locations of national operator logistic infrastructure (depot sites, past and present research stations, tractor train routes, major traverses, etc.) would further enhance this representation and increase its usefulness to environmental policy makers. With the availability of low-cost hand-held Global Positioning System (GPS) technology, future collection of direct location records of human activities in Antarctic may be feasible without substantial cost.

If such information were available, vulnerable locations may be identified more easily and protected, based not only on physical parameters (for instance, provided by the Environmental Domains Analysis; Morgan et al. 2007) or biological diversity (see work by the SCAR Evolution and Biodiversity in Antarctic Programme; http://www.eba.aq/), but also on levels of human visitation. All three parameters are essential for effective environmental management and future systematic protected area designation.

\section{Do untouched areas exist in Antarctica?}

Our analyses demonstrate that substantially sized unvisited areas are scarce on the Peninsula, with the Lassiter Coast (south-east Peninsula, between the Werner Mountains and Scaife Mountains) being the last large ice-free area unvisited by UK personnel (Fig. 6). Depending upon the 
past activities of other NAPs, this area may contain candidate sites for protection as inviolate areas preserved for future scientific efforts. Further afield, candidate sites may also exist in the Trans-Antarctic Mountains and Marie Byrd Land (Lewis Smith 1994).

Antarctic Specially Protected Area (ASPA) 123 Barwick and Balham valleys, southern Victoria Land, remains the only substantial area protected primarily to conserve the natural ecosystem as a reference area largely undisturbed by direct human activities. At $480 \mathrm{~km}^{2}$, this site is the largest terrestrial ASPA, accounting for around a third of Antarctica's specially protected land, yet it represents less than $1 \%$ of the continent's ice-free ground (see http://www.ats.aq/documents/recatt/ Att445_e.pdf). Other much smaller ASPAs, or zones within ASPAs, have been designated with access restricted i) to preserve the ecosystem as largely undisturbed by human activities (ASPA 119 Davis Valley and Forlidas Pond, Dufek Massif, Pensacola Mountains), ii) to act as reference sites for future comparative studies (ASPA 116 New College Valley, Caughley Beach, Cape Bird, Ross Island), or iii) for future microbiological research using metagenomic techniques (ASPA 126 Byers Peninsula, Livingston Island, South Shetland Islands) (http://www.ats.aq/e/ep_protected.htm).

Human presence at a location is not always essential in order to gain site-specific information. The rapid on-going development of satellite and airborne remote sensing techniques (including multi- and hyperspectral analysis) may provide increasingly detailed information on an area's geology, hydrology, geomorphology and vegetation cover without the need for human visitation (Fretwell et al. 2010). Nevertheless, collection of detailed information, such as site biodiversity, will inevitably require site visits.

\section{Conclusions}

Information on the activities of the NAP within Antarctica held in field reports and archive and science databases could be used to give environmental managers and policymakers a greater insight into levels of human impact across the continent. This is essential because all Antarctic research, tourism and exploration has an environmental cost. The establishment of new NAP stations and infrastructure may further facilitate the visitation of increasingly remote area of Antarctica - an activity that shows little sign of abatement. Even the most remote areas of Antarctica are now potentially accessible to humans, and already impacted through low level pollution, and may be at risk from microbial contamination and redistribution of biota. Over forthcoming decades, scientific methodologies will undoubtedly progress, but the continued existence of unvisited Antarctic sites, as pristine natural laboratories for future science, may be in doubt. Inevitably, scientists and policy makers need to balance the need to visit new areas of Antarctica to answer pressing scientific questions, with that to protect and preserve areas of Antarctic for future science or other purposes or values. Future science is at risk if this balance is not given adequate consideration both in Antarctica and other unimpacted areas of the Earth.

\section{Acknowledgements}

We thank Ian Collinge for historical information, Helen Campbell for information on SCADM, Magdalena Biszczuk for assistance with mapping, Pete Convey for helpful comments on a late draft of the manuscript and two anonymous reviewers for useful comments following submission. This paper contributes to the British Antarctic Survey's Polar Science for Planet Earth core programme EO-LTMS (Environment Office - Long Term Monitoring and Survey).

\section{References}

ASOC (Antarctic And Southern OCEAn CoAlition). 2004. Environmental reports of Fildes Peninsula, 1988-1997: benchmarks for environmental management. Antarctic and Southern Ocean Coalition report, December 2004, 15 pp. Available at: http://www.asoc.org/Portals/0/ASOC\% 20Fildes\%20Peninsula\%20inspections\%20review\%202004.pdf.

ATCP (Antarctic Treaty Consultative Parties). 1991. Protocol on environmental protection to the Antarctic Treaty. CM 1960. London: HMSO, 38 pp.

Baker, G.C., Tow, L.A. \& Cowan, D.A. 2003. PCR-based detection of non-indigenous microorganisms in 'pristine' environments. Journal of Microbiological Methods, 53, 157-164.

Bargagli, R. 2005. Antarctic ecosystems: environmental contamination, climate change and human impact. Berlin: Springer, 395 pp.

Blanchette, R.A., Held, B.W., Jurgens, J.A., Aislabie, J., Duncan, S. \& FARRELL, R.L. 2004. Environmental pollutants from the Scott and Shackleton expeditions during the 'Heroic Age' of Antarctic exploration. Polar Record, 40, 143-151.

Braun, C., Mustafa, O., Nordt, A., Pfeiffer, S. \& Peter, H.-U. In press. Environmental monitoring and management proposals for the Fildes Region (King George Island, Antarctica). Polar Research.

Broady, P.A. \& SMith, R.A. 1994. A preliminary investigation of the diversity, survivability and dispersal of algae introduced into Antarctica by human activity. Proceedings of the NIPR Symposium on Polar Biology, 7, 185-197.

Cameron, R.E. 1972. Pollution and conservation of the Antarctic terrestrial ecosystem. In Parker, B.C., ed. Proceedings of the colloquium on conservation problems in Antarctica. Lawrence, KS: Allen Press, 267-308.

Campbell, I.B., Claridge, G.G.C. \& Balks, M.R. 1998. Short and longterm impacts of human disturbance on snow-free surfaces in Antarctica. Polar Record, 34, 15-24.

Chen, J. \& Blume, H.-P. 1997. Impact of human activities on the terrestrial ecosystem of Antarctica: a review. Polarforschung, 65, 83-92.

Chown, S.L. \& Convey, P. 2007. Spatial and temporal variation across life's hierarchies in the terrestrial Antarctic. Philosophical Transactions of the Royal Society, B362, 2307-2331.

COMnap (Council Of Managers Of National Antarctic Programs). 2010. Antarctic facilities. www.comnap.aq/facilities. Accessed 10 December 2010.

Conlan, K.E., Kim, S.L., Lenihan, H.S. \& Olivers, J.S. 2004. Benthic changes during 10 years of organic enrichment by McMurdo Station, Antarctica. Marine Pollution Bulletin, 49, 43-60. 
Fox, A.J. \& CoOPer, A.P.R. 1998. Climate-change indicators from archival aerial photography of the Antarctic Peninsula. Annals in Glaciology, 27, 636-642.

FRANCE. 2008. A mechanism for centralizing tourism and nongovernmental activity declarations and authorization requests suitable for taking cumulative impacts into account. Working Paper 034 for XXXI Antarctic Treaty Consultative Meeting, Committee for Environmental Protection. Kiev, Ukraine, 2-13 June 2008.

Frenot, Y., Chown, S.L., Whinam, J., Selkirk, P.M., Convey, P., Skotnicki, M. \& Bergstrom, D.M. 2005. Biological invasions in the Antarctic: extent, impacts and implications. Biological Reviews, 80, 45-72.

Fretwell, P.T., Convey, P., Fleming, A.H., Peat, H.J. \& Hughes, K.A. 2010. Detecting and mapping vegetation distribution on the Antarctic Peninsula from remote sensing data. Polar Biology, 34, 273-281.

Headland, R. 2009. A chronology of Antarctic exploration. London: Quaritch, $722 \mathrm{pp}$.

Hughes, K.A. 2003. Aerial dispersal and survival of sewage-derived faecal coliforms in Antarctica. Atmospheric Environment, 37, 3147-3155.

Hughes, K.A. 2004. Reducing sewage pollution in the Antarctic marine environment using a sewage treatment plant. Marine Pollution Bulletin, 49, 850-853.

Hughes, K.A. 2010. How committed are we to monitoring human impacts in Antarctica? Environmental Research Letters, 5, 041001.

Hughes, K.A. \& Blenkharn, N. 2003. A simple method to reduce discharge of sewage microorganisms from an Antarctic research station. Marine Pollution Bulletin, 46, 353-357.

Hughes, K.A. \& Convey, P. 2010. The protection of Antarctic terrestrial ecosystems from inter- and intra-continental transfer of non-indigenous species by human activities: a review of current systems and practices. Global Environmental Change, 20, 96-112.

Hughes, K.A. \& NobBs, S. 2004. Long-term survival of human faecal microorganisms on the Antarctic Peninsula. Antarctic Science, 16, 293-297.

Hughes, K.A. \& Worland, M.R. 2010. Spatial distribution, habitat preference and colonisation status of two alien terrestrial invertebrate species in Antarctica. Antarctic Science, 22, 221-231.

Hughes, K.A., Convey, P., Maslen, N.R. \& Smith, R.I.L. 2010. Accidental transfer of non-native soil organisms into Antarctica on construction vehicles. Biological Invasions, 12, 875-891.

iaAto (International Association Of Antarctica Tour Operators). 2010. Tourism statistics. http://www.iaato.org/tourism_stats.html. Accessed 10 December 2010.

JABOUR, J. 2009. National Antarctic programs and their impact on the environment. In KerRy, K.R. \& Riddle, M.J., eds. Health of Antarctic wildlife - a challenge for science and policy. Heidelberg: Springer, 211-229.

Kennicutt, M.C., Klein, A., Montagna, P., Sweet, S., Wade, T., Palmer, T., Sericano, J. \& Denoux, G. 2010. Temporal and spatial patterns of anthropogenic disturbance at McMurdo Station, Antarctica. Environmental Research Letters, 5, 034010.

LeE, J.E. \& CHOwn, S.L. 2009a. Quantifying the propagule load associated with the construction of an Antarctic research station. Antarctic Science, 21, 471-475.

Lee, J.E. \& Chown, S.L. 2009b. Breaching the dispersal barrier to invasion: quantification and management. Ecological Applications, 7, 1944-1959.
Lee, J.E. \& Hughes, K.A. 2010. Guest editorial: focused tourism needs focused monitoring. Antarctic Science, 22, 1.

Lewis Smith, R.I. 1994. Environmental-geographic basis for the protected area system. In Lewis Smith, R.I., Walton, D.W.H. \& Dingwall, P.R., eds. Developing the Antarctic protected area system. Cambridge: IUCN, 27-36.

Lynch, H.J., Crosbie, K., FAgan, W.F. \& NaveEn, R. 2010. Spatial patterns of tour ship traffic in the Antarctic Peninsula region. Antarctic Science, 22, 123-130.

Mellars, P. 2006. Why did modern human populations disperse from Africa ca. 60000 years ago? A new model. Proceedings of the National Academy of Science of the United States of America, 103, 9381-9386.

Meyer, G.H., Morrow, M.B. \& Wyss, O. 1963. Viable organisms from faeces and foodstuffs from early Antarctic expeditions. Canadian Journal of Microbiology, 9, 163-167.

Morgan, F., Barker, G., Briggs, C., Price, R. \& Keys, H. 2007. Environmental domains of Antarctica. Version 2.0. Final report. Landcare Research Contract Report LC0708/055. Lincoln: Landcare Research New Zealand Ltd, 89 pp.

Nedwell, D.B., Russell, N.J. \& Cresswell-Maynard, T. 1994. Longterm survival of microorganisms in frozen material from early Antarctic base camps at McMurdo Sound. Antarctic Science, 6, 67-68.

Nuastad, B., ed. 1998. Report of the Antarctic Protected Areas workshop 23 May, 1998, Tromso, Norway. Tromso: Norsk Polarinstitutt, 87 pp.

Santos, I.R., Silva, E.V., Schaefer, C.E.G.R., Alburquerque, M.R. \& CAMPos, L.S. 2005. Heavy metal contamination in coastal sediments and soils near the Brazilian Antarctic Station, King George Island. Marine Pollution Bulletin, 50, 185-194.

Sheppard, D.S., Claridge, G.G.C. \& Campbell, I.B. 2000. Metal contamination of soils at Scott Base, Antarctica. Applied Geochemistry, 15, 513-530.

SJoling, S. \& Cowan, D.A. 2000. Detecting human bacterial contamination in Antarctic soils. Polar Biology, 23, 644-650.

Smith, J.J. \& RiddLe, M.J. 2009. Sewage disposal and wildlife health in Antarctica. In KerRy, K.R. \& RiddLe, M.J., eds. Health of Antarctic wildlife - a challenge for science and policy. Heidelberg: Springer, 271-315.

Tejedo, P., Justel, A., Benayas, J., Rico, E., Convey, P. \& Quesada, A. 2009. Soil trampling in an Antarctic Specially Protected Area: tools to assess levels of human impact. Antarctic Science, 21, 229-236.

Tin, T., Fleming, Z.L., Hughes, K.A., Ainley, D.G., Convey, P., Moreno, C.A., Pfeiffer, S., Scott, J. \& SNAPE, I. 2009. Impacts of local human activities on the Antarctic environment. Antarctic Science, 21, 3-33.

United States. 2003. Final report from the intersessional contact group on cumulative environmental impacts. Working Paper 006 for XXVI Antarctic Treaty Consultative Meeting, Committee for Environmental Protection. Madrid, Spain, 9-20 June 2003.

Whinam, J., Chilcott, N. \& Bergstrom, D.M. 2005. Subantarctic hitchhikers: expeditioners as vectors for the introduction of alien organisms. Biological Conservation, 121, 207-219.

WiLKNEss, P. 1990. Fuel spill clean up in the Antarctic. Antarctic Journal of the United States, 25(4), 3-8.

WaLton, K. \& AtKinson, R. 1996. Of dogs and men: fifty years in the Antarctic - the illustrated story of the dogs of the British Antarctic Survey 1944-1994. Malvern Wells: Images Publishing (Malvern) Ltd, $190 \mathrm{pp}$. 